\title{
Effect of different nutrient diets on developmental and reproductive fitness of Pink bollworm, Pectinophora gossypiella (Lepidoptera: Gelechiidae)
}

Madhu T N ( $\nabla$ madhuentomology@gmail.com )

University of Agricultural Sciences https://orcid.org/0000-0003-1657-4087

Muralimohan $\mathrm{K}$

University of Agricultural Sciences

Arunkumara C G

University of Agricultural Sciences

Nagaraju M C

University of Agricultural Sciences

Research Article

Keywords: Cotton, Diet, Fecundity, Okra and P. gossypiella

Posted Date: August 23rd, 2021

DOl: https://doi.org/10.21203/rs.3.rs-752895/v1

License: (a) (i) This work is licensed under a Creative Commons Attribution 4.0 International License. Read Full License

Version of Record: A version of this preprint was published at Journal of Entomological Research on December 29th, 2021. See the published version at https://doi.org/10.5958/0974-4576.2021.00100.6. 


\section{Abstract}

Pink bollworm, Pectinophora gossypiella (Lepidopetra: Gelechiidae) is one of the most important pest of cotton. In this paper, we studied the influence of different nutrient rearing diets on developmental and reproductive characteristics of pink bollworm under laboratory conditions. Larvae were reared on four diets (two natural diets and two artificial diets) with varied nutritional value. Larval diet affects the survival, development duration, pupal weight, adult emergence and fecundity. Pink bollworm attained the fastest larval development on NRD (19.8 days) with a survival rate of 88.2\% and slowest on NPD and okra ( 27.1 days) with a survival rate of $47.5 \%$ and $58.1 \%$ respectively. Pupal weight was highest $(26.86 \mathrm{mg}$ ) on NRD and reached maximum fecundity (107 eggs/female), while lowest fecundity on NPD (37 eggs/female). Among natural diets, egg hatching rate on cotton and okra were $87 \%$ and $71 \%$. Adult emergence starts early and the adult eclosion window was narrow on cotton and NRD. Adult longevity was varied with diets, while female moths lived longer than males in all diet treatments. Our study may help to understanding the effect of nutrition from different diets and enhanced the fecundity of $P$. gossypiella on NRD under laboratory conditions.

\section{Introduction}

Pink bollworm, Pectionphora gossypiella (Saunders) has evolved as a most destructive insect pest of cotton and distributed in all cotton growing regions of the world. Cotton is a primary food crop for pink bollworm and well adopted to Gosyppium hirsutum (Upland /Mexican cotton) compared to other Gosyppium spp. However, it gained the status as stenophagous species and co-evolved with other malvaceae group of plants such as okra, roselle, kenaf and deccan hemp (6). Nutrition plays a vital role in optimal metabolic activity of an insect. The type of food resource acquisition in the larval stage is expected to affect all developmental process and reproductive fitness (21). During the process of embryogenesis, maternal resources are utilized for production of offspring's. Whereas, in active acquisition period (larva), quality and quantity of nutrients from the diet determine the body mass and reproduction capacity in adults (3). However, during pupal stage insect undergoes a progressive transformation and allocates the energetic resource for different metabolic process (9). The ingestion of nutrient constituents i.e. carbon, nitrogen, sugars from primary metabolites and other secondary metabolites such as phenols, terpenoids, tannins etc. from different food source may influence the normal transformational process.

Requirement of proteins, lipids, sugars, vitamins and other inorganic salts in many insect species are almost similar (13). However, the necessity of individual nutrients may vary among different groups of insects. Any slight variation in composition of diet may have profound impact on growth and development of an insect. Notably, the ultimate fitness in lepidoptera rely on both quantity and quality of food consumed during active feeding stage of an insect $(22,31)$. The availability and acquisition of nutrients in larval stage influences and determines the adult life history traits and hence type of diet is crucial for insect fitness. These have been documented in many species of Lepidoptera and Hymenoptera $(5,26)$.

An appropriate mass production technique is crucial for conducting research involving target insects. Though, the larvae of pink bollworm mainly feed on cotton (natural diet) may not be feasible option to rear 
this insect in the laboratory. However, different artificial diets have been proposed for rearing $P$. gossypiella under controlled conditions $(1,25,20,8)$. Further, mass culturing of pink bollworm was mostly carried out on artificial diets to study the biology, behavior and also to conduct bioassays with insecticides including Bt toxins. However, the influence of natural diets on overall development and reproductive fitness of an insect cannot be ruled out. Though, the biology of $P$. gossypiella has been studied on artificial diets $(2,28)$, the information regarding significance of specific constituents of diet on its development and reproduction is limited. The development and reproduction of $P$. gossypiella on different nutritional diet is still a cause of concern for many researchers. In this study we aim to systematically study the influence of nutrition on development and reproductive biology of $P$. gossypiella when fed with nutritionally rich and poor diets comprising of both natural and artificial diets.

\section{Materials And Methods}

\section{Pink bollworm culture}

The pink bollworm infested cotton bolls were collected from cotton fields at Raichur, Karnataka, India $\left(16^{\circ} 12^{\prime} 2.9^{\prime \prime} \mathrm{N}\right.$ and $\left.77^{\circ} 21^{\prime} 44^{\prime \prime} \mathrm{E}\right)$. Thus collected bolls were placed inside the plastic container $(60 \times 30 \mathrm{~cm}$, covered with muslin cloth) at $26 \pm 2^{0} \mathrm{C}$ temperature, $70 \pm 10 \mathrm{RH}$ and $14 \mathrm{~h}$ light till pupation in the laboratory. Male and female pupae were separated based on the pupal morphological characters i.e. position of genital and anal pores (between 9th and 10th in $\otimes \&$ 8th and 10th in $\varangle$ ). Emerged moths were released into the ovipositional cage $(45 \times 45 \times 60 \mathrm{~cm})$. Fresh cotton twigs were offered as substrate for oviposition and piece of cotton soaked with $10 \%$ honey solution was provided as food for adults.

\section{Rearing diets}

The study was conducted on four diets comprising two natural diets and two artificial diets in the Department of entomology, University of Agricultural Sciences, Bengaluru. The diets were categorized into nutritionally rich and nutritionally poor diets both in natural and artificial food sources. Cotton (Gossypium hirsutum) and Okra (Abelmoschus esculentus) were used as natural diets. Here, cotton was considered as nutritionally rich source and okra as nutritionally poor diet based on natural preference/selection of host plants by P. gossypiella. In artificial diets, we improved the proportion of some of the constituents like yeast, ascorbic acid, casein and sucrose content in the existing diet protocol for pink bollworm (8) and named as 'Nutrient Rich Diet' (NRD). While, the quantity of some essential nutrients such as yeast, sucrose, casein and ascorbic acid was limited from the reference diet and considered as Nutrient Poor Diet (NPD) (Table 1). 
Table 1

Nutrient composition of artificial diets

\begin{tabular}{|c|c|c|c|}
\hline \multicolumn{2}{|c|}{ Ingredients (in grams) } & \multirow{2}{*}{$\begin{array}{l}\text { Nutrient Rich Diet (NRD) } \\
200\end{array}$} & \multirow{2}{*}{$\begin{array}{l}\text { Nutrient Poor Diet (NPD) } \\
200\end{array}$} \\
\hline Component A & Chickpea flour (Kabuli) & & \\
\hline & Wheat germ & 50 & 50 \\
\hline & Casein & 40 & 20 \\
\hline & Sucrose & 40 & 20 \\
\hline & Wessons salt & 10 & 10 \\
\hline & Ascorbic acid & 06 & 03 \\
\hline & Sorbic acid & 1.6 & 1.6 \\
\hline & Methyl paraben & 03 & 03 \\
\hline & Cholesterol & 1.3 & 1.3 \\
\hline & Streptomycin sulphate & 0.5 & 0.5 \\
\hline & Bavistin & 04 & 04 \\
\hline & Distilled water (mL) & 600 & 600 \\
\hline \multirow[t]{2}{*}{ Component B } & Yeast & 32 & 16 \\
\hline & Distilled water (mL) & 300 & 300 \\
\hline \multirow[t]{2}{*}{ Component C } & Agar & 24 & 24 \\
\hline & Distilled water $(\mathrm{mL})$ & 300 & 300 \\
\hline
\end{tabular}

\section{Insect rearing procedure on different diets}

The newly hatched larvae were individually released into the transparent plastic boxes $(60 \mathrm{~mm}$ in diameter X $50 \mathrm{~mm}$ height) containing cut pieces of cotton bolls and okra fruits separately. Artificial diet was prepared as per the standardized protocol (8). Prepared diet was cut into small cakes (weighing approximately $5 \mathrm{gm}$ ) and transferred into 24 well plate (Sigma-Aldrich, $16 \mathrm{~mm}$ dia). Later, neonate larvae were transferred individually into each well. A total of 120 larvae were reared on each diet to study the developmental and reproductive biology of $P$. gossypiella. Cephalic capsule length was measured in each instar to determine the development process of pink bollworm larvae on rearing diets using Leica microscope fitted with ocular micrometer (CH-9435). The natural diets and artificial diets (NRD and NPD) were changed and replaced with fresh diet once in three days and five days, respectively. Larvae were separated into males and females at

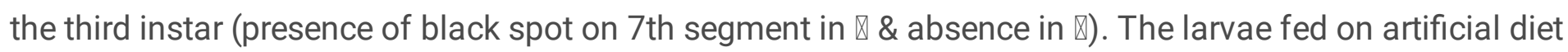
pupated on the diet substrate itself, whereas in natural diet larvae pupated inside the cotton boll /okra fruit. Male and female pupae were weighed and recorded using analytical balance on the day of pupation and total pupal duration was also documented. 
Reproductive biology was studied by using 15 pairs of adults in each of the diets. Freshly emerged adults of $P$. gossypiella were released in pair into the rearing cages $(30 \times 30 \times 45 \mathrm{~cm})$. Young cotton twigs were placed inside the cages as substrate for oviposition and $10 \%$ percent honey solution as moth diet. The total number of eggs laid on each day were counted under microscope and cotton twigs were replaced daily. Other biological parameters such as larval duration, pupal weight and pupal duration, pre-oviposition and oviposition periods, fecundity, fertility percent, adult longevity and total life cycle were recorded. In addition to these observations, the influence of diet on size of spermathecae in female moths was also determined by dissecting freshly emerged moths and spermathecae was measured using Leica microsystem $(\mathrm{CH}-9435$ Heerbrugg: DFC450).

The data was analyzed using one-way analysis of variance (ANOVA) followed by LSD as a post-hoc test and statistical significance among treatments were estimated at $5 \%$ probability level. Relationship between female pupal weight and fecundity was analyzed using Pearson correlation co-efficient. Data was analyzed using IBM SPSS statistics ver. 20 (IBM, Armonk, NY, USA).

\section{Results}

\section{Larval and adult development}

Pink bollworm completed its development on all the diets assessed. However, the developmental process at various stages of $P$. gossypiella was faster on NRD (artificial diet) followed by cotton boll diet. On the other hand, the developmental parameters of larvae and adults were greatly affected on okra and NPD. Significant differences were recorded in the cephalic capsule length of second $(F=4.98, P<0.005)$, third $(F=10.27, P<$ $0.001)$ and fourth instar $(F=9.11, P<0.001)$ larval stage, on all diets (Table 2$)$. The total larval and pupal durations on NRD was shorter than other diets $(F=28.42, P<0.001 ; F=8.40, P<0.001)$. Whereas, larval and pupal development on okra and NPD were considerably longer (Table 3 ). Adult longevity was longest on NRD and shortest on NPD. In all the treatments, female moths $(F=13.46, P<0.001)$ lived longer than male moths $(F=5.49, P<0.003)$.

Table 2

Cephalic capsule length of different instar larvae

\begin{tabular}{|lllll|}
\hline Treatment & \multicolumn{4}{l}{ Cephalic capsule length $(\mathrm{mm})$} \\
\cline { 2 - 5 } & I instar & II instar & III instar & IV instar \\
\hline Cotton & $0.04 \pm 0.01 \mathrm{a}$ & $0.13 \pm 0.14 \mathrm{bc}$ & $0.49 \pm 0.29 \mathrm{bc}$ & $0.98 \pm 0.45 \mathrm{ab}$ \\
\hline Okra & $0.03 \pm 0.04 \mathrm{a}$ & $0.11 \pm 0.06 \mathrm{a}$ & $0.40 \pm 0.15 \mathrm{ab}$ & $0.86 \pm 0.28 \mathrm{a}$ \\
\hline NRD & $0.04 \pm 0.05 \mathrm{a}$ & $0.15 \pm 0.10 \mathrm{c}$ & $0.55 \pm 0.28 \mathrm{c}$ & $1.08 \pm 0.42 \mathrm{~b}$ \\
\hline NPD & $0.03 \pm 0.04 \mathrm{a}$ & $0.11 \pm 0.05 \mathrm{a}$ & $0.38 \pm 0.23 \mathrm{a}$ & $0.84 \pm 0.27 \mathrm{a}$ \\
\hline $\begin{array}{l}\text { Numbers within columns followed by the same letter are not statistically different by LSD test at } 5 \% \\
\text { level of probability }\end{array}$ & \multicolumn{4}{l}{} \\
\hline
\end{tabular}


Table 3

Developmental biology (in days) of Pink bollworm reared on natural and artificial diets

\begin{tabular}{|c|c|c|c|c|c|c|c|}
\hline Treatment & $\begin{array}{l}\text { Egg } \\
\text { incubation } \\
\text { period }\end{array}$ & $\begin{array}{l}\text { Total } \\
\text { larval } \\
\text { period }\end{array}$ & $\begin{array}{l}\text { Larval } \\
\text { survival } \\
\text { (\%) }\end{array}$ & $\begin{array}{l}\text { Pupal } \\
\text { period }\end{array}$ & $\begin{array}{l}\text { Pupation } \\
\text { percentage } \\
\text { (\%) }\end{array}$ & $\begin{array}{l}\text { Average } \\
\text { pupa weight } \\
\text { (mg) }\end{array}$ & $\begin{array}{l}\text { Emergence } \\
\text { rate }(\%)\end{array}$ \\
\hline Cotton & $\begin{array}{l}5.70 \pm \\
0.42 a\end{array}$ & $\begin{array}{l}24.72 \pm \\
0.73 \mathrm{~b}\end{array}$ & $\begin{array}{l}67.50 \pm \\
5.10 \mathrm{~b}\end{array}$ & $\begin{array}{l}9.52 \pm \\
0.32 \mathrm{~b}\end{array}$ & $\begin{array}{l}80.40 \pm \\
2.56 \mathrm{~b}\end{array}$ & $\begin{array}{l}20.56 \pm \\
0.64 \mathrm{~b}\end{array}$ & $\begin{array}{l}80.40 \pm \\
5.46 \mathrm{c}\end{array}$ \\
\hline Okra & $\begin{array}{l}6.50 \pm \\
0.34 a\end{array}$ & $\begin{array}{l}27.16 \pm \\
0.58 \mathrm{c}\end{array}$ & $\begin{array}{l}58.10 \pm \\
3.55 a b\end{array}$ & $\begin{array}{l}10.40 \\
\pm \\
0.40 \mathrm{bc}\end{array}$ & $\begin{array}{l}55.80 \pm \\
4.85 a\end{array}$ & $\begin{array}{l}16.02 \pm \\
0.45 a\end{array}$ & $\begin{array}{l}53.40 \pm \\
3.08 \mathrm{~b}\end{array}$ \\
\hline NRD & $\begin{array}{l}5.20 \pm \\
0.24 a\end{array}$ & $\begin{array}{l}19.84 \pm \\
0.60 a\end{array}$ & $\begin{array}{l}88.20 \pm \\
2.08 c\end{array}$ & $\begin{array}{l}8.16 \pm \\
1.81 \mathrm{a}\end{array}$ & $\begin{array}{l}89.40 \pm \\
2.08 \mathrm{~b}\end{array}$ & $\begin{array}{l}26.86 \pm \\
0.60 \mathrm{c}\end{array}$ & $\begin{array}{l}89.80 \pm \\
1.78 c\end{array}$ \\
\hline NPD & $\begin{array}{l}6.10 \pm \\
0.38 a\end{array}$ & $\begin{array}{l}27.24 \pm \\
3.42 \mathrm{c}\end{array}$ & $\begin{array}{l}47.50 \pm \\
3.26 \mathrm{a}\end{array}$ & $\begin{array}{l}10.72 \\
\pm \\
0.48 \mathrm{c}\end{array}$ & $\begin{array}{l}53.80 \pm \\
4.38 a\end{array}$ & $\begin{array}{l}14.20 \pm \\
0.45 a\end{array}$ & $\begin{array}{l}47.20 \pm \\
3.72 \mathrm{a}\end{array}$ \\
\hline
\end{tabular}

\section{Survival rate and pupal weight}

The larval nutrition significantly affected the survival rate and pupal weight of $P$. gossypiella. The larval survival rate was maximum on NRD (88.20\%) followed by cotton $(67.50 \%)$. In contrast, the survival rate was minimum on NPD (47.50\%) and okra (58.10\%) (Table 3). Further, larval diet also influenced the rate of pupation $(F=23.59, P<0.001)$, pupal weight $(F=105.87, P<0.001)$ and adult emergence $(F=43.62, P<$ 0.001). The pupal weight of $P$. gossypeilla was significantly higher on NRD and lowest on NPD diet. Furthermore, rate of pupation and adult emergence per cent was maximum on NRD and it was considerably low on NPD and okra diets.

\section{Adult reproductive characteristics}

Larval diet had significant influence on reproductive fitness of $P$. gossypiella. The results showed that, adult eclosion period was lengthy on NPD and okra, whereas eclosion window was found to be narrow on NRD and cotton diets (Fig. 1. Differences in male and female moth emergence of $P$. gossypiella feeding on different diets. Peak emergence was recorded on different days after pupation. Sample sizes are indicated in the parenthesis). Further, male moths emerged slightly earlier than female moths. Significant differences were recorded in fecundity, fertility, adult longevity and total life cycle between diets (Table 4). However, differences observed on pre-mating and ovipositional period in all the diet treatments were non-significant. Though, the average number of eggs per female was highest on NRD diet, the fertility percentage was maximum on cotton $(87.10 \%)$ followed by NRD (83.50\%). Lowest fecundity and fertility percentage was recorded on NPD and okra diets. Total life cycle of $P$. gossypiella was shorter on NRD compared to natural diets $(F=10.09, P<0.001)$. A positive correlation was noticed between pupal weight and fecundity on all the diets $(r=0.723, P<0.001)$. 
Table 4

Reproductive biology of Pink bollworm reared on different nutritional diet

\begin{tabular}{|c|c|c|c|c|c|c|c|}
\hline Treatment & $\begin{array}{l}\text { Premating } \\
\text { period } \\
\text { (days) }\end{array}$ & $\begin{array}{l}\text { Oviposition } \\
\text { period } \\
\text { (days) }\end{array}$ & $\begin{array}{l}\text { Fecundity } \\
\text { (no. of } \\
\text { eggs/female) }\end{array}$ & $\begin{array}{l}\text { Fertile } \\
\text { eggs } \\
(\%)\end{array}$ & $\begin{array}{l}\text { Total life } \\
\text { cycle } \\
\text { (days) } \\
\text { (egg to } \\
\text { next } \\
\text { generation } \\
\text { egg } \\
\text { hatch) }\end{array}$ & $\begin{array}{l}\text { Adult } \\
\text { longevity } \\
\text { in days } \\
\text { (Female) }\end{array}$ & $\begin{array}{l}\text { Adult } \\
\text { longevity } \\
\text { in days } \\
\text { (Male) }\end{array}$ \\
\hline Cotton & $\begin{array}{l}3.20 \pm \\
0.20 \mathrm{a}\end{array}$ & $\begin{array}{l}6.50 \pm \\
0.34 a\end{array}$ & $91.80 \pm 4.85 c$ & $\begin{array}{l}87.1 \\
\pm \\
1.22 \mathrm{~b}\end{array}$ & $\begin{array}{l}45.70 \pm \\
1.58 b\end{array}$ & $\begin{array}{l}13.30 \pm \\
0.65 \mathrm{bc}\end{array}$ & $\begin{array}{l}11.10 \pm \\
0.61 \mathrm{~b}\end{array}$ \\
\hline Okra & $\begin{array}{l}3.40 \pm \\
0.27 a\end{array}$ & $\begin{array}{l}6.10 \pm \\
0.43 a\end{array}$ & $56.80 \pm 2.80 b$ & $\begin{array}{l}71.0 \\
\pm \\
1.52 \mathrm{a}\end{array}$ & $\begin{array}{l}48.80 \pm \\
1.47 \mathrm{bc}\end{array}$ & $\begin{array}{l}11.80 \pm \\
0.91 \mathrm{ab}\end{array}$ & $\begin{array}{l}9.60 \pm \\
0.48 \mathrm{ab}\end{array}$ \\
\hline NRD & $\begin{array}{l}3.00 \pm \\
0.21 \mathrm{a}\end{array}$ & $\begin{array}{l}6.50 \pm \\
0.37 a\end{array}$ & $107.10 \pm 5.0 c$ & $\begin{array}{l}83.50 \\
\pm \\
1.44 \mathrm{~b}\end{array}$ & $\begin{array}{l}40.40 \pm \\
1.67 a\end{array}$ & $\begin{array}{l}15.60 \pm \\
0.54 \mathrm{c}\end{array}$ & $\begin{array}{l}11.30 \pm \\
0.65 \mathrm{~b}\end{array}$ \\
\hline NPD & $\begin{array}{l}3.18 \pm \\
0.11 \mathrm{a}\end{array}$ & $\begin{array}{l}5.10 \pm \\
1.19 a\end{array}$ & $37.20 \pm 3.68 a$ & $\begin{array}{l}66.0 \\
\pm \\
2.88 a\end{array}$ & $\begin{array}{l}52.50 \pm \\
1.76 c\end{array}$ & $\begin{array}{l}9.60 \pm \\
0.58 a\end{array}$ & $\begin{array}{l}8.30 \pm \\
0.65 a\end{array}$ \\
\hline
\end{tabular}

\section{Spermathecal size}

The effect of different nutritional diet on development of spermathecae was assessed and results suggested that significant variation in the length of spermathecae in all the treatments $(F=22.23, P<0.001)$. The maximum spermathecal length $(1.35 \pm 0.26 \mathrm{~mm})$ was recorded on NRD and width of spermathecae across the treatments was non-significant (Table 5) (Fig. 5. Differences in size of spermathecae of $P$. gossypiella reared on different diets. Length of spermathecae was significant between the diet groups $(\mathrm{P}<$ 0.000). (Scale bar $-1 \mathrm{~mm})$ ).

Table 5

Size of spermathecae on different diets.

\begin{tabular}{|lll|}
\hline \multirow{2}{*}{ Treatment } & \multicolumn{2}{l|}{ Spermathecae size $(\mathrm{mm})$} \\
\cline { 2 - 3 } & Length & Width \\
\hline Cotton & $1.19 \pm 0.12 \mathrm{bc}$ & $0.48 \pm 0.17 \mathrm{~b}$ \\
\hline Okra & $1.13 \pm 0.18 \mathrm{ab}$ & $0.40 \pm 0.38 \mathrm{a}$ \\
\hline NRD & $1.35 \pm 0.26 \mathrm{c}$ & $0.55 \pm 0.72 \mathrm{c}$ \\
\hline NPD & $1.06 \pm 0.35 \mathrm{a}$ & $0.40 \pm 0.36 \mathrm{a}$ \\
\hline Number and means $( \pm \mathrm{SE})$ followed by different letters are significant at the 0.05 level \\
\hline
\end{tabular}




\section{Discussion}

The nourishment derived from natural and artificial diets (both resource rich and poor conditions) does influence the developmental biology and reproduction characteristics in insects. Although, several standardized mass rearing diets are available for rearing $P$. gossypiella, the researchers continue to study the appropriate composition of constituents in diets to optimize development and reproduction fitness. The range of host plants, their nutritional contents and presence of secondary substances affect the development and reproductive process in many lepidopteran herbivores $(33,34)$. Through this research work, we empirically demonstrated how larval nutrition from different diets influence the developmental and reproductive fitness of $P$. gossypiella.

The nutritional quality and quantity of food sources have direct effect on vital aspects of the biology of insects $(14,22)$. In the current study, we found that, though growth and development of $P$. gossypiella was faster on NRD, the larvae fed on cotton bolls equally resulted in many developmental parameters of pink bollworm. It is due to, cotton is widely considered as most suitable host plant for $P$. gossypiella (23) and hence the insect is believed to be acquire proper nourishment. Nutrient constituents were high both qualitatively and quantitatively in NRD, yet, there was no significant difference between NRD and cotton diets with respect to many developmental parameters. In contrast, duration of larval development was considerably longer on okra and NPD diets. The variation in cephalic capsule length in different instars of larvae were observed and recorded maximum cephalic capsule length on NRD suggesting larvae obtained maximum nutrition and grew larger size compared to other treated diets. It is probably due to availability of greater proportion of nutrients in NRD diet for P. gossypiella and no constraints of exposure to plant secondary metabolites, unlike in natural diets. Presence of secondary metabolites like gossypol in cotton is known to implicit negative impact on survival of $P$. gossypiella larvae and incurred greater energy to degrade such unpalatable content (7). The larval survival rate was low on NPD and it is largely due to deficient quantities of some nutrients such as yeast, sugar, casein and ascorbic acid. Some studies reported that, deficiency in nutrient supplements such as ascorbic acid in the diet resulted in poor survival of larvae of boll weevil, bollworm, Heliothis zea and no survival of salt marsh caterpillar, suggesting importance of every ingredient in the artificial diets (30). Ascorbic acid at 3200 ppm in artificial diets is known to significantly support the growth and development of tobacco caterpillar (17). In general, the nutritional status and larval fitness are likely to be reflected at pupal stage $(11,18)$. Hence, $P$. gossypiella displayed faster larval development and recorded maximum pupal weight on NRD and cotton diets. Furthermore, the development of $P$. gossypiella on NPD and okra diets were slower and attained lowest pupal weight due to insufficient or limitation in nutrient supplements. A positive relationship between female pupal weight and fecundity was noticed on different diets. Pupal weight possibly is an indication of nutrition status at larval stage of insects that regulates the normal growth and fecundity (19). Emergence of moths were also influenced by feeding diets. Adult emergence started early on cotton and NRD diets and was slightly delayed on okra and NPD diets. Interestingly, we observed emergence of males earlier to females on all the diets and adult emergence window was narrow on NRD.

Fitness of insects is greatly enhanced under optimal larval feeding conditions $(4,32)$. The role of nutrients in the feeding diets during larval stage play a vital role in fecundity and fertility of an insect. Maximum 
fecundity of $P$. gossypiella was recorded on NRD compared to NPD due to the presence of optimum quantities of yeast, sugar, casein and ascorbic acid. These diet constituents were significantly reduced in NPD, which may have affected the adult reproductive fitness. The decrease in quantity of hydrolyzed yeast significantly reduced the fecundity and ovary maturation in tephritids (15). Similarly, boll weevil laid fewer eggs when fed with ascorbic acid deficient diet and thus considered as an indispensable nutrient for insect growth and development (30). Between natural diets that we assessed, both fecundity and fertility was significantly higher on cotton compared to okra. Contrast to our findings, other studies reported that higher fecundity of $P$. gossypiella when larvae were fed with okra over cotton $(29,28)$. Furthermore, quality and quantity of nutrients is known to have an influence on size and development of spermatheace in insects. Diameter of spermathecae was highest in queen honey bees reared on artificial diet coupled with honey and pollen compared to other diets (10). Similarly, we also observed the maximum length of spermathecae on NRD followed by cotton and lowest spermathecal length on NPD.

P. gossypiella completed its life cycle much faster on NRD and slightly slower on cotton diet. It is possibly due to lesser proportion of nutrients in cotton bolls compared to artificial diet (NRD) and due to the presence of other constitutes viz., terpenes, phenols, proteins, carbohydrates, fatty acids and lipids may slowdown the developmental process (12). On the other hand, okra fruit mostly contains polyphenolic compounds and reduced proportion of nutritive substances like amino acids, fatty acids and carbohydrates which supports normal growth and development of $P$. gossypiella $(16,24,27)$. Hence, among the natural diets, the developmental parameters (larval survival percentage, rate of pupation, pupal weight and adult emergence) and reproductive fitness (fecundity and fertility) of pink bollworm was significantly superior on cotton than on okra.

In this study, we demonstrated the overall performance of $P$. gossypiella on nutrient rich and poor conditions of both natural and artificial diets. The developmental and reproductive characteristics of pink bollworm including larval survival rate, pupal weight, adult emergence, fecundity and fertility was significantly superior on greater proportion of nutrient diet (NRD) compared to other artificial and natural diets. Therefore, it suggested that maximum fecundity of pink bollworm can be achieved through our improvised diet under laboratory conditions.

\section{Declarations}

\section{Acknowledgements}

Authors thank Dr. Chinnababu Naik, Scientist, ICAR- Central Institute for Cotton Research, Nagpur, for his assistance in laboratory rearing of pink bollworm.

\section{Authors contribution}

TNM - Conceptualization, Investigation, Analysis, Writing - Original draft preparation.

MK - Investigation, Review and Editing.

ACG - Analysis, Review and Editing. 
NMC - Analysis, Review and Editing.

Conflict of Interest: Authors declares that there have no conflict of interest.

\section{References}

1. Adkisson PL. Fecundity and Longevity of the Adult Female Pink Bollworm Reared on Natural and Synthetic Diets. J Econ Entomol. 1961;54:1224-7.

2. Ahmed DA. Fecundity, egg fertility and longevity of laboratory reared the pink bollworm, Pectinophora gossypiella (Lepidoptera: Gelichidiea) under different adult diet regimes. Egyptian J Plant Prot Res Inst. 2009;2:151-60.

3. Arrese EL, Soulages JL. Insect fat body: energy, metabolism and regulation. Ann Rev Entomol. 2010;55:207-25.

4. Barros EM, Torres JB, Ruberson JR, Oliveira MD. Development of Spodoptera frugiperda on different hosts and damage to reproductive structures in cotton. Entomol Exp et Appl. 2010;137:237-45.

5. Boggs CL. Reproductive strategies of female butterflies: variation in and constraints on fecundity. Ecol Entomol. 1986;11:7-15.

6. CABI. Invasive species compendium: Pectinophora gossypiella (pink bollworm). 2017. Available from URL: https://www.cabi.org/isc/datasheet/39417\#70AF7142-7A8B-4F36-A0BA-4F14FA270EED, accessed on 21/11/2017.

7. Carriere Y, Yelich AJ, Degain BA, Harpold VS, Unnithan GC, Kim JH, Mathew LG, Head GP, Rathore KS, Fabrick JA, Tabashnik BE. Gossypol in cottonseed increases the fitness cost of resistance to Bt cotton in pink bollworm. Crop prot. 2019;126, https://doi.org/10.1016/j.cropro.2019.104914.

8. Dhara Jothi B, Chinna BabuNaik V, Kranthi S, Kranthi KR, Valarmathi. (2016) Viable mass production method for cotton pink bollworm, Pectinophora gossypiella (Saunders), The J Basic \& Appl Zool. 2016;73, 9-12.

9. Denlinger DL, Zdarek J. Metamorphosis behavior of flies. Ann Rev Entomol. 1994;39:243-66.

10. Dolasevic S, Stevanovic J, Aleksic N, Glavinic U, Deletic N, Mladenovic M, Stanimirovic Z. The effect of diet types on some quality characteristics of artificially reared Apis mellifera queens. J Api Res. 2020;59:115-23.

11. Eduardo MS, Julián P, Pablo MC, Diego TT, Valeria PC, Ignacio MS. Pupal emergence pattern in cactophilic Drosophila and the effect of host plants. Insect Sci. 2018;25:1108-18.

12. Egbuta MA, Mclntosh S, Daniel LE, Waters, Vancov T, Liu L. Biological Importance of Cotton ByProducts Relative to Chemical Constituents of the Cotton Plant. Molecules 2017;22, Article ID 93. https://doi.org/10.3390/molecules22010093.

13. Fang J, Zhu L, Yang ZD. Advances and problems in insect artificial diet studies. J Sichuan Fores Sci Techn. 2003;24:18-26.

14. Frank AE, Dietz A. Growth and survival of Galleria mellonella (Lepidoptera: Pyralidae) larvae fed diets containing honey bee-collected plant resins. An Entomol Soc Amer. 1987;80:4-77. 
15. Goane L, Pereyra F, Castro MJ, Ruiz ML, Juárez DF, Segura, Vera MT. Yeast derivatives and wheat germ in the adult diet modulates fecundity in a tephritid pest. Bull Entomol Res. 2018;109:178-90.

16. Jain N, Jain R, Jain V, Jain SA. Review on: Abelmoschus esculentus. Pharmacia. 2012;1:84-9.

17. Sharma K, Shridhar J, Sharma RK. effects of dietary antioxidants on growth and development of taro caterpillar. Indian J exp biol. 2018;56:129-35.

18. Li Y, Leng CM, Hu D, Wu JX, Li YP. Effects of host plants on growth, development and fecundity of Plutella xylostella L. Acta Agri Boreali-occidentalis Sinica. 2019;28:475-80.

19. Liu ZD, Li DM, Gong PY, Wu KJ. Life table studies of the cotton bollworm, Helicoverpa armigera (Hubner) (Lepidoptera: Noctuidae), on different host plants. Environ Entomol. 2004;33:1570-6.

20. Muralimohan K, Kamath SP, Mohan KS, Ravi KC, Deeba F, Sivasupramaniam S. Mass rearing diet for the pink bollworm Pectinophora gossypiella (Lepidoptera: Gelechiidae) and its susceptibility to insecticidal Bt proteins. Int J Trop Insect Sci. 2009;29:102-07.

21. Nestel D, Papadopoulos NT, Pascacio-Villafán C, Righini N, Altuzar-Molina AR, Aluja M. Resource allocation and compensation during development in holometabolous insects. J Insect Physiol. 2016;95:78-88.

22. Pashley DP, Ardí TN, Hammond AM. Host effects on developmental and reproductive traits in fall armyworm strains (Lepidoptera: Noctuidae). An Entomol Soc America. 1995;88:748-55.

23. Pearson EO. The Insect Pests of Cotton in Tropical Africa. London: Empire Cotton Growing Corporation and Commonwealth Institute of Entomology; 1958. p. 355.

24. Petropoulos S, Fernandes Â, Barros L, Ferreira ICFR. Chemical composition, nutritional value and antioxidant properties of Mediterranean okra genotypes in relation to harvest stage. Food Chem. 2018;242:466-74.

25. Raulston JR. A Practical Diet Containing Cottonseed for Rearing the Pink Bollworm. J Econ Entomol. 1971;64:1021-3.

26. Rivero A, Giron D, Casas J. Lifetime allocation of juvenile and adult resources to egg production in a holometabolous insect. Proc Royal Soc London B. 2001;268:1231-7.

27. Roy A, Shrivastava SL, Mandal SM. Functional properties of Okra Abelmoschus esculentus L. (Moench): Traditional claims and scientific evidences. Plant Sci Today. 2014;1:121-30.

28. Shrinivas AG, Sreenivas SG, Hanchinal S, Beldhadi RV. Comparative biology of pink bollworm, Pectinophora gossypiella (Saunders) (Lepidoptera: Gelechiidae) on different hosts. J Entomol Zool Stud. 2019;7:1053-60.

29. Syed ST, Abro GH, Khanum A, Sattar M. Effect of host plants on the biology of Erias vittella (Fab) (Noctuidae: Lepidoptera) under laboratory conditions. Pakistan J Zool. 2011;43:127-32.

30. Vanderzant ES, Pool MC, Richardson CD. The role of ascorbic acid in the nutrition of three cotton insects. J Insect Physiol. 1962;8:287-97.

31. Wigglesworth VB. The principles of insect physiology. London: Methuen; 1965:;741p.

32. Xu PJ, Zhang DD, Wang J, Wu KM, Wang XW, Wang XF, Ren GW. The host preference of Spodoptera frugiperda on maize and tobacco. Plant Prot. 2019;45:61-4. 
33. Zhang LL, Li YH, Wu JX. Effects of various host plants on the development and protective enzyme activity of the black cutworm, Agrotis ypsilon. Chinese J Appl Entomol. 2013;0:1049-54. (in Chinese).

34. Zhang S, Wu MF, Gu SH, Li XC. Oviposition preference of female adults of Helicoverpa armigera to 16 host plants and larval performance. Plant Prot. 2019;45:108-13. (in Chinese).

\section{Figures}
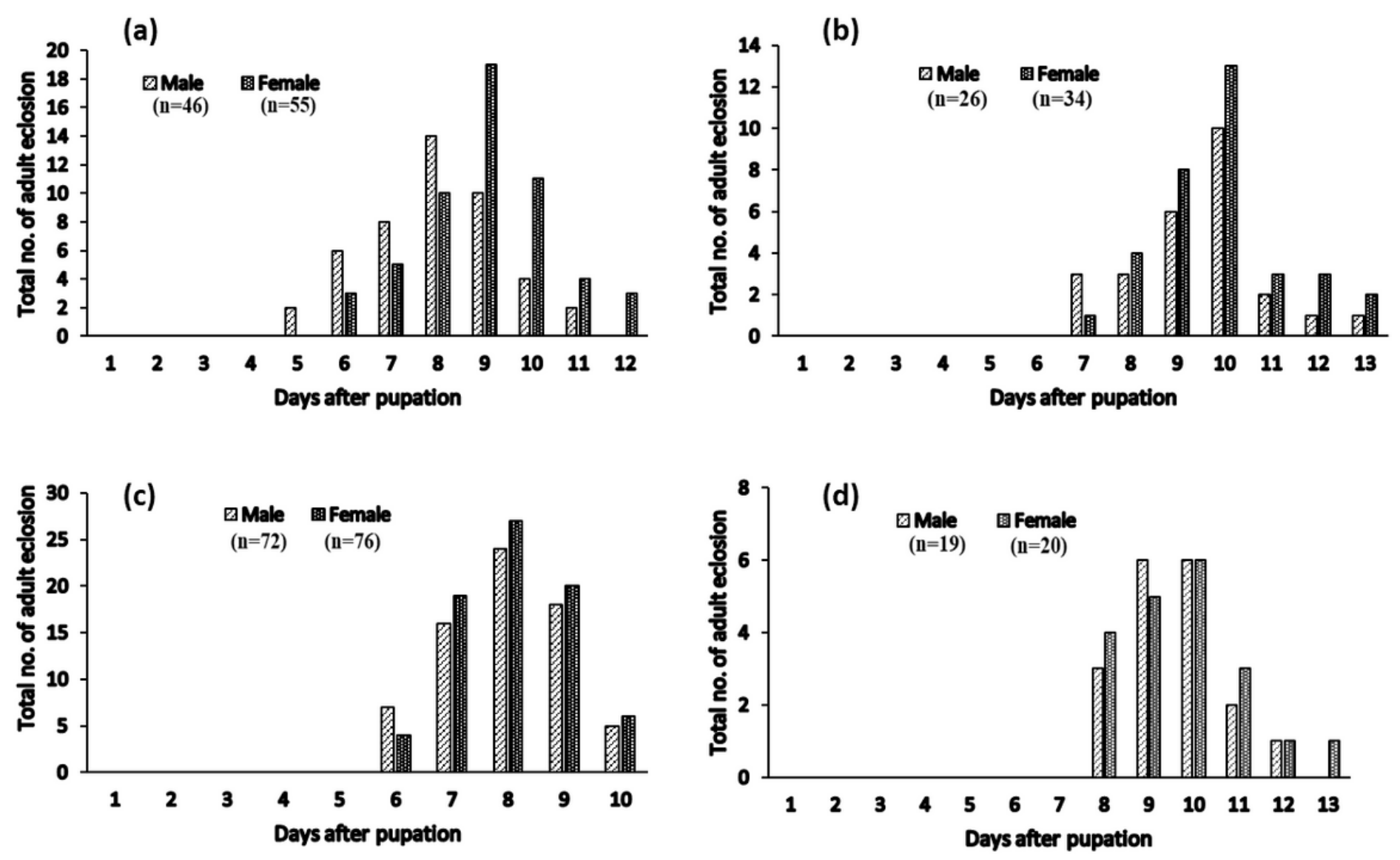

Figure 1

Differences in male and female moth emergence of P. gossypiella feeding on different diets. Peak emergence was recorded on different days after pupation. Sample sizes are indicated in the parenthesis 


\section{Image not available with this version}

Figure 2

Image not available with this version

\section{Image not available with this version}

Figure 3

Image not available with this version

\section{Image not available with this version}

Figure 4

Image not available with this version 


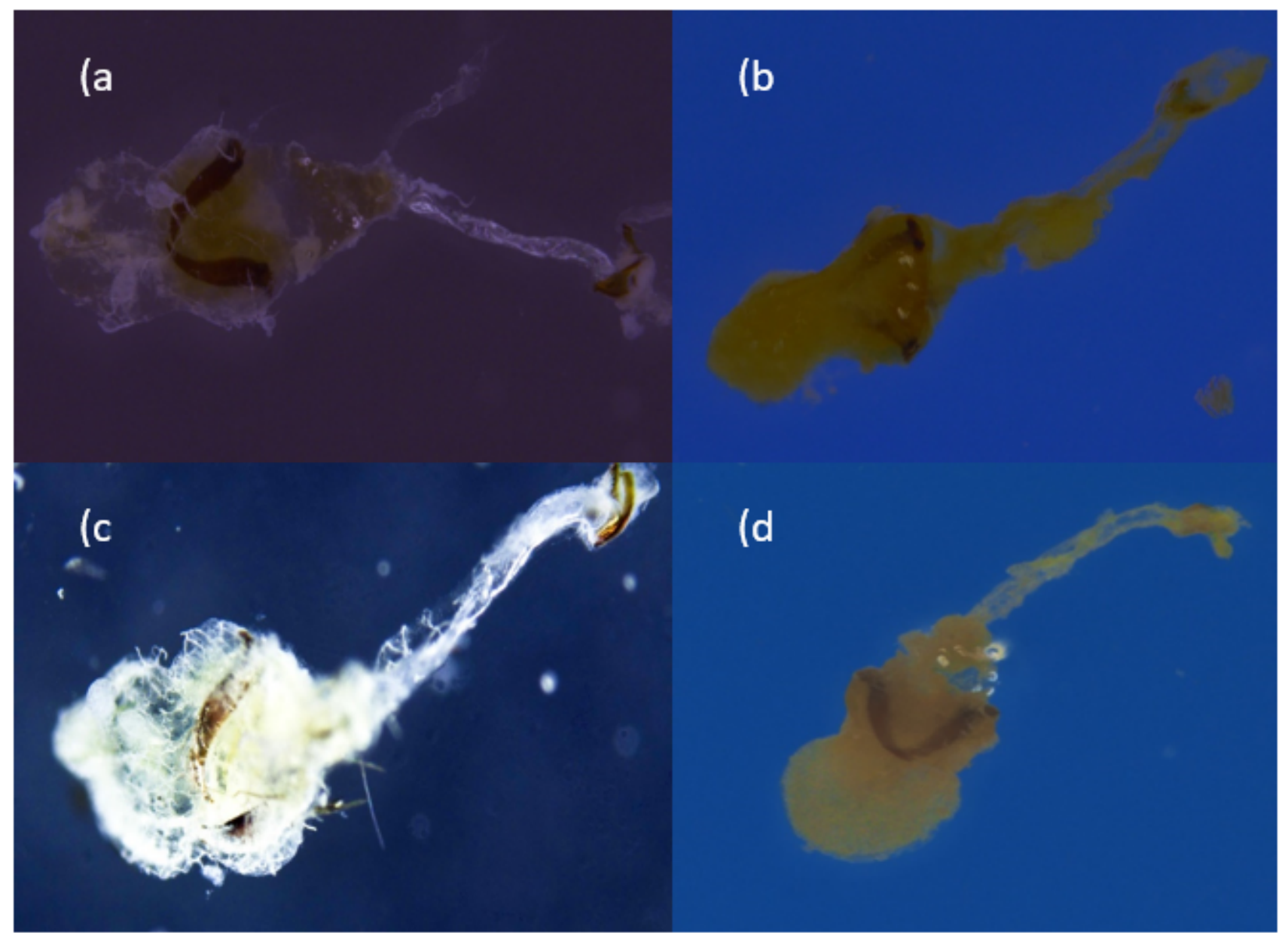

\section{Figure 5}

Differences in size of spermathecae of P. gossypiella reared on different diets. Length of spermathecae was significant between the diet groups $(P<0.000)$. (Scale bar $-1 \mathrm{~mm}$ ) 